\title{
Thermal Burn
}

National Cancer Institute

\section{Source}

National Cancer Institute. Thermal Burn. NCI Thesaurus. Code C50768.

A burn injury caused by heat or fire. 